DOI: https://doi.org/10.47405/mjssh.v5i4.390

\begin{tabular}{|c|c|}
\hline 84 & Malaysian Journal of Social Sciences and Humanities (MJSSH) \\
\hline $\begin{array}{l}\text { Malaysian Journal of } \\
\text { Social cSiences and }\end{array}$ & Volume 5, Issue 4, April 2020 \\
\hline (MJ - SSH) & e-ISSN : 2504-8562 \\
\hline & $\begin{array}{l}\text { Journal home page: } \\
\text { www.msocialsciences.com }\end{array}$ \\
\hline
\end{tabular}

\title{
A Study on Customer Satisfaction Towards Ambiance, Service and Food Quality in Kentucky Fried Chicken (KFC), Petaling Jaya
}

\author{
Nurfatihah Zamani', Nur Afiqah Binti Bahrom¹, Nor Shafiqah Binti Meor Fadzir1, Nur Syakirah Binti \\ Mohd Ali @ Mohd Fauzy1, Nurul Farzana Binti Anua1, Saidatul Assyirah Binti Rosman¹, Semitaa \\ Sivam $^{1}$, Kausalya Muthutamilselvan ${ }^{2}$, Isai Amutan Krishnan ${ }^{3}$ \\ 1University Malaya Centre for Continuing Education (UMCCed), University of Malaya (UM) \\ ${ }^{2}$ Lorong 2A/5 Taman Mutiara, Sg. Kob Karangan, Kulim, Kedah \\ ${ }^{3}$ Faculty of Languages and Linguistics, University of Malaya (UM)
}

Correspondence: Isai Amutan Krshnan (amutan.isai@gmail.com)

\begin{abstract}
This case study is on customer satisfaction towards ambiance of facilities, service, and food quality from a behavioural perspective. The study is aimed at investigating customer complaints on the unhygienic conditions and bad attitude of staff during working hours in KFC Petaling Jaya, Malaysia (Laeranduil, 2018). The research examined the impact of food quality, investigated the effect of service quality and identified the influence of ambiance on customer satisfaction. To achieve the study goals, the researcher designed a questionnaire to collect data from randomly selected customers in KFC Petaling Jaya. From the questionnaires distributed to respondents, 294 were returned. The study's results on food quality showed that most respondents agreed that KFC serves good quality food at KFC Petaling Jaya. For service quality, most of the respondents agreed that the crew at KFC Petaling Jaya serve customers well. For ambiance of the facilities, most of the respondents agreed that the ambiance in KFC Petaling Jaya is pleasing. Overall, the customers surveyed were satisfied with the ambiance of the facilities, service, and food quality of KFC Petaling Jaya.
\end{abstract}

Keywords: customer satisfaction, ambiance, attitude, food quality

\section{Introduction}

In this modern era, fast food has become common and a significant part of most people's busy everyday existence. Two of the most well-known fast food restaurants in Malaysia are McDonald's and Kentucky Fried Chicken (KFC). By far, Kentucky Fried Chicken (KFC) has, for a long period of time, been one of the most successful companies in the fast food industry. Kentucky Fried Chicken, founded by Colonel Harland Sanders, focuses on providing the best chicken in town. In 1973, KFC Malaysia opened their first restaurant on Jalan Tuanku Abdul Rahman. Presently, KFC Malaysia has approximately 600 restaurants in Malaysia, and regardless of the large number of locations, the restaurants are generally considered to be well managed.

Nevertheless, KFC Malaysia has received criticism regarding the average food quality, bad services provided by staff and the facilities provided in some restaurants. Regarding these and other issues, however, KFC would like to gain customer satisfaction as it creates customer loyalty toward KFC. 
According to Hanaysha and Hilman (2015), customer loyalty can be obtained if the product or services that are provided fulfil customer expectations and lead to customer satisfaction.

Cross-sectional research on sustained consumer preferences relating to the Malaysian fast food market could determine how KFC can remain competitive with other fast food restaurants such as McDonald's and Burger King (Hui \& Zheng, 2010). Cross-sectional research could also define and predict how long KFC could stay in the Malaysian fast food market in light of complaints received (Laeranduil, 2018) about worker attitudes and the hygiene of Malaysian KFC restaurants. Food and service quality are the main factors that influence customer satisfaction. Moreover, the ambiance of facilities also has an impact on customer satisfaction (Laeranduil, 2018).

In the extended context of the new global economy, KFC Malaysia's restaurant operations have become central to issues of customer satisfaction towards their service quality, food quality and ambiance. A key aspect in relation to mitigating problems arising from such customer satisfaction issues is KFC Malaysia's awareness of the extent to which the cleanliness of each restaurant is maintained by responsible parties to provide a comfortable environment for customers. In addition, staff attitude is very important during working hours as it is indicative of how management and staff handle problems occurring in KFC restaurants.

Customer complaints that KFC restaurant environments are not hygienic, and that staff exhibit bad attitudes during working hours collectively represent a major problem for the company's future. Thus, the purpose of this study is to provide information and create awareness about customer satisfaction toward KFC general guidelines about coefficient extent and the quality of the connections are followed (Haider, Jan, Jan \& Jan, 2007).

Therefore, this study focused on how KFC Petaling Jaya can assure customer satisfaction with their restaurant's hygiene as well as the variety of food served and make sure that the customers are satisfied with the food quality (Laeranduil, 2018). A good atmosphere in a fast food restaurant and reasonable pricing contribute to customer satisfaction (Dharaminder Kaur Chahal, 2017). A restaurant's quality and image can be inferred from the cleanliness of its surroundings. Based on the issues that KFC received from Laeranduil (2018), service quality is also an important element or factor that can influence customer satisfaction. Therefore, the purpose this study is to investigate customer satisfaction towards service quality, food quality and ambiance provided by KFC in Malaysia.

\section{Literature Review}

\section{Customer Satisfaction}

Customer satisfaction is determined through evaluation of customers' experiences with and perceptions of products or services and whether both of them meet customer expectations in fulfilling their needs and wants. According to Ali, Kim, Li, and Jeon (2016), freedom of choice affects customer satisfaction. For example, restaurant customers could be satisfied and give good feedback when they have the opportunity of choosing menu items for themselves. Other than that, customer loyalty can result if provided products or services fulfil their expectations (Hanaysha \& Hilman, 2015). Previous research by Abdul and Zainal (2016), for example, explored the relationship between quality and customer satisfaction using five independent variables: perceived value, emotional price, monetary price, behavioural price and reputation.

\section{Ambiance of Facilities}

Based on previous research, the cleanliness of restaurant surroundings must be prioritized to give satisfaction to customers. The objective of restaurant ambiance is to provide customers a comfortable environment while eating in the restaurant and directly fulfil their expectations 


\section{Service Quality}

According to Sundho (2015) and Swanson and Chen (2016), all industries identify service quality as a global concept. The objective of service quality is to fulfil the satisfaction of customers toward the services that are given. In addition, the staff must serve customers with kindness and show a good attitude in interacting with the customers. Previous research has stated that the quality of services provided has an influence on customers (Olise, Okoli, \& Ekeke, 2015). Thus, if high service quality is given, the result will be higher customer satisfaction. Sumaedi and Yarmen (2015) suggested a benefit quality demonstrate for eateries in Islamic nations. Their demonstrate comprises of eight measurements: common physical environment, Islamic physical environment, nourishment quality, holding up time, staff, handle, Islamic-related skill and halal quality. Jaini, Ahmad and Zaib (2015) examined the components that influence the benefit quality of fast-food eateries, considering the relationship between client encounter and add up to quality. They utilized three fundamental measurements to degree the whole quality of eateries: benefit quality, nourishment quality and air quality.

In their study on traditional restaurants in Vietnam, Dao and Tin (2015) examined the relationship between service quality and customer satisfaction to measure service quality in restaurants.

\section{Food Quality}

Food quality is a very important element that influences the satisfaction and purchase intentions among customers. The objective of managing food quality is to enhance the image and brand recognition of products and services. According to Md. Sawari, Ghazali, Ibrahim and Mustapha (2015), restaurants that display Halal logos represent the practice of healthier lifestyles, which produces effective impacts on the development of the businesses. In enhancing the quality of food, restaurants should provide fresh and well-cooked meals to maintain quality food. Ko and Su (2015) carried out a study findout the most variables of nourishment benefit quality. They distinguished two categories of measurements related to items and clients. The item category comprised item character, culinary expressions and cleanliness and security.

\section{Past Studies}

Previous studies have reported that service quality influenced customer satisfaction. Research by Dipesh Karki and Apil Panthi (2018) investigated the impact of the factors of price, service quality, restaurant ambiance and food quality on customer satisfaction in Nepalese restaurants, and the study found that all the factors effected customer satisfaction. Ayed Al Muala's (2018) research had the same independent variables, but price was an additional unique element. The aim was to study the relationships between promotion, brand awareness, trust and brand association and their influence on customer satisfaction. This study was a bit different from other studies because there were some elements that were unique. From the above research, brand awareness, trust and brand association have been found to influence customer satisfaction with fast food restaurants. In addition, the research by Hasan, Polas, Rahman, Miah and Ali Hayash (2018) has shown the relationship between the factor of waiting time and customer satisfaction. The finding revealed that service quality had the most impact on waiting time toward customer satisfaction. Moreover, a study by Lahap Johanudin, Azlan, Bahri, Said Noraslinda Abdullah and Dahlan Zain Razlan (2018) had the same objective and used the same method. It found that the perceived waiting time influenced customer satisfaction. Furthermore, a study by Rizwan Qaisar, Shakir Waqas Tariq, Shahan Ali, Hafiz Fawad, Khan Muhammad and Shahid Rabia. (2018) examined the factors of product quality and customer satisfaction and their impact on customer satisfaction and customer loyalty in fast food restaurants. The findings of this study revealed that service quality and customer expectations are related to customer satisfaction and customer loyalty.

Research has investigated the relationships of price, service and food quality, facilities and emotional states to customer satisfaction (Dastane \& Intan Fazlin, 2017). All factors produce impacts on customer satisfaction but the most significant found in past studies are emotional factors and facilities. Chalal 
and Naail Mohammad Kamil's (2017) research objective was to study the relationship between three independent variables: service and food quality and the atmosphere of a restaurant. The research found that the three independent variables influenced customer satisfaction.

A study by Willy (2017) investigated the relationship between service quality provided based on a customer's gender and customer satisfaction in fast food restaurants. The study organised service quality into three dimensions, which included tangibles, reliability and assurance. The finding revealed differences in customer satisfaction between assurance and tangibles based on gender (female and male), and that a prediction can be made on customer satisfaction based on service quality dimensions.

Research conducted by Almohaimmed (2017) investigated the relationships between restaurant quality such as halal status, hygiene, menu, atmosphere, quality assurance, accuracy, responsiveness, interior design, external environment and price and their influence on customer satisfaction. The results revealed that halal status is unquestionably influential among customers. The finding was that all the dimensions of service quality influenced customer satisfaction. The methodology used in the study relied on questionnaires for data collection.

A previous study by Aziam Mustafa (2017) investigated the effects of product and service quality on buyer's satisfaction toward Prima Home. The research used quantitative methods for data analysis. The result was that the most significant factor influencing buyer satisfaction was service quality.

Ya, Noor, Nor and Ahmad (2017) study aimed to determine the relationships between customer perception and customer loyalty and their effects on customer purchase intentions. The finding was that customer perception influenced purchase intention toward Islamic branding.

According to past research by Manjunath and Reginald (2016), the factors which affected customer satisfaction were service quality, product quality, physical design, price, physical environment, taste and promotion. The key factors found in this previous research to have the most significant influences on customer satisfaction were service quality and physical design. Research conducted by Bhagat (2016) had the same basic objective, but included some other factors that influence customer satisfaction, which were healthier fast food menus and brands, but physical design and environment were not found to be factors that influence customer satisfaction. The study revealed the key factors are taste, price, variety and employee service or service quality. In addition, a previous research study by Jalal Hanasya (2016) stated that it was about food quality, price and environment as factors that impact customer satisfaction. In this study the most significant finding was that food quality influenced customer satisfaction.

A study by Mushtaq, Mirza, Ali Asghar, Muhammad (2012) investigated the relationship between customer satisfaction with fast food services, food quality and perceived value and the customer relationship with management. It was found that the customer relationship's effect on customer satisfaction was influential in management improving the performance of a company. A study by Herman (2016) investigated the relationships of the factors of quality, brand identity and Korean popular culture with decisions on product purchases. Both previous studies used quantitative data collected through questionnaires. The findings revealed that customers had good perceptions of the factors that influenced their decision making on purchases.

In research on the hospitality industry, a study by Szymanski and Henard (2015) examined tourists' expectations and perceptions regarding the service quality of resorts and hotels. The study performed quantitative analysis on the collected data. The perception is main influenced that expectation which has shown as a result.

Al- Tit (2015) conducted a study to investigate the relationships between service quality, food quality, customer satisfaction and customer retention in a restaurant in Jordan. The methodology used in this past study employed questionnaires distributed among students. The study found that service quality and food quality significantly affected customer satisfaction. Moreover, the most influential factors related to customer retention were the service quality dimensions. This result shows there is a 
relationship between customer satisfaction and customer retention. Moreover, the impact of employees' ethical behaviour on customer satisfaction and customer retention was studied by Basnayake and Zubair Hassan (2015). The study revealed that employee's ethical behaviour has a significant impact on customer satisfaction and customer retention when it is expressed in employees' attitudes toward customers. Both past studies used quantitative analyses of data from questionnaires. Shariff, Omar, Sulong, Majid, Ibrahim, Jaafar, Ideris (2015) studied the influence of service quality and food quality on customer satisfaction. They found that both service quality and food quality are significant antecedents of customer satisfaction. Moreover, a previous study by Wong, Chew, and Loh (2015) investigated factors affecting customer loyalty in the telecommunications industry such as services, customer value, and corporate image. The study found that the influencing factors had correlations with each other.

Lastly, previous research on KFC in China compared KFC and McDonald's. The study aimed to determine the factors that influenced customers to choose between KFC and McDonald's such as price, delivery, availability, environment of product, behaviour of staff and value for money (Muhammad Usman Haider et al., 2012). The quantitative data was collected from questionnaires distributed to a few respondents. The finding reveals that the less significant factor which influenced choice was value for money. This study found that KFC was better than McDonald's.

Based on the previous studies, there are various factors that affect customers. As found in these studies, the main factors that affect customer satisfaction are service quality, restaurant ambiance and food quality (El-Adly \& Eid, 2016; Han \& Hyun, 2015, 2017). No previous study has investigated the factors that influence customer satisfaction at KFC Petaling Jaya, Malaysia. Therefore, the current research aimed to investigate survey respondents' perceptions of the services, food quality and ambiance that are provided by KFC Petaling Jaya. We chose to conduct this research because KFC received complaints about the unhygienic conditions and bad attitude of staff during working hours in that restaurant (Laeranduil, 2018).

\section{Methodology}

\section{Conceptual Framework}

Figure 1 shows the independent variable (IV) consists of three factors, which are food quality, service quality and ambiance of facilitates. These relate to the dependent variable (DV), which is customer satisfaction. The independent variable relates to the problem statement that KFC received complaints about the unhygienic conditions and bad attitude of staff during working hours at KFC Petaling Jaya (Laeranduil, 2018) and no previous study has investigated the factors that influence customer satisfaction at KFC Petaling Jaya, Malaysia. Therefore, the current study investigated respondents' perceptions toward the services, food quality and ambiance that are provided by KFC Petaling Jaya.

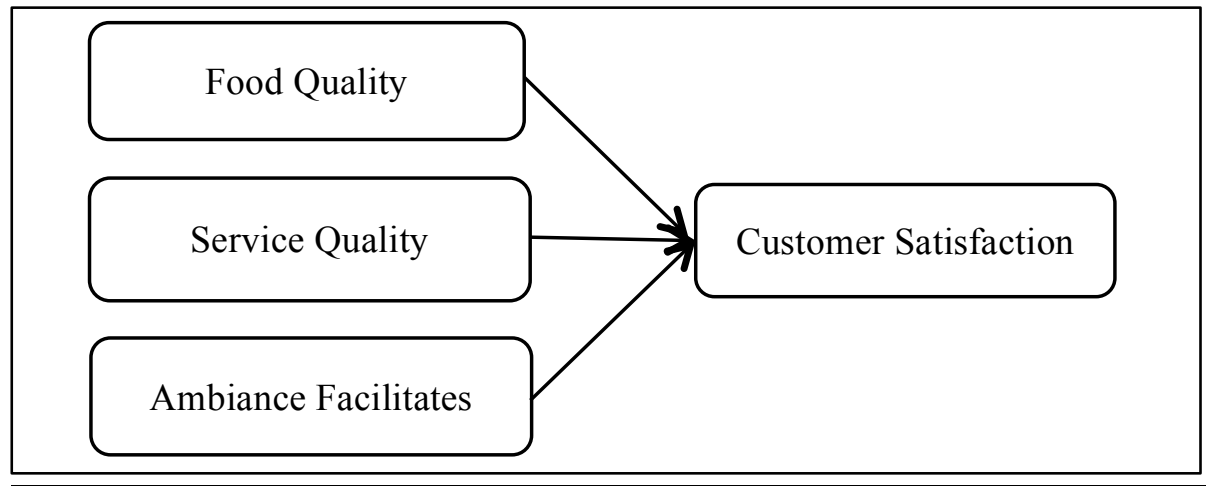

Figure 1. Conceptual Framework

Source: Dipesh and April (2018) 
Figure 2 shows an overview of the research design consisting of setting, sampling and instruments. Based on setting in the research design, the study was conducted in KFC Petaling Jaya, Kuala Lumpur. This study employed a quantitative analytical approach utilising SPSS statistical tests version 25 (Jackson, 2011). Consent was obtained to collect the data. The data were collected in KFC Petaling Jaya, Kuala Lumpur, Malaysia. This place was chosen based on easy accessibility (Creswell, 2014).

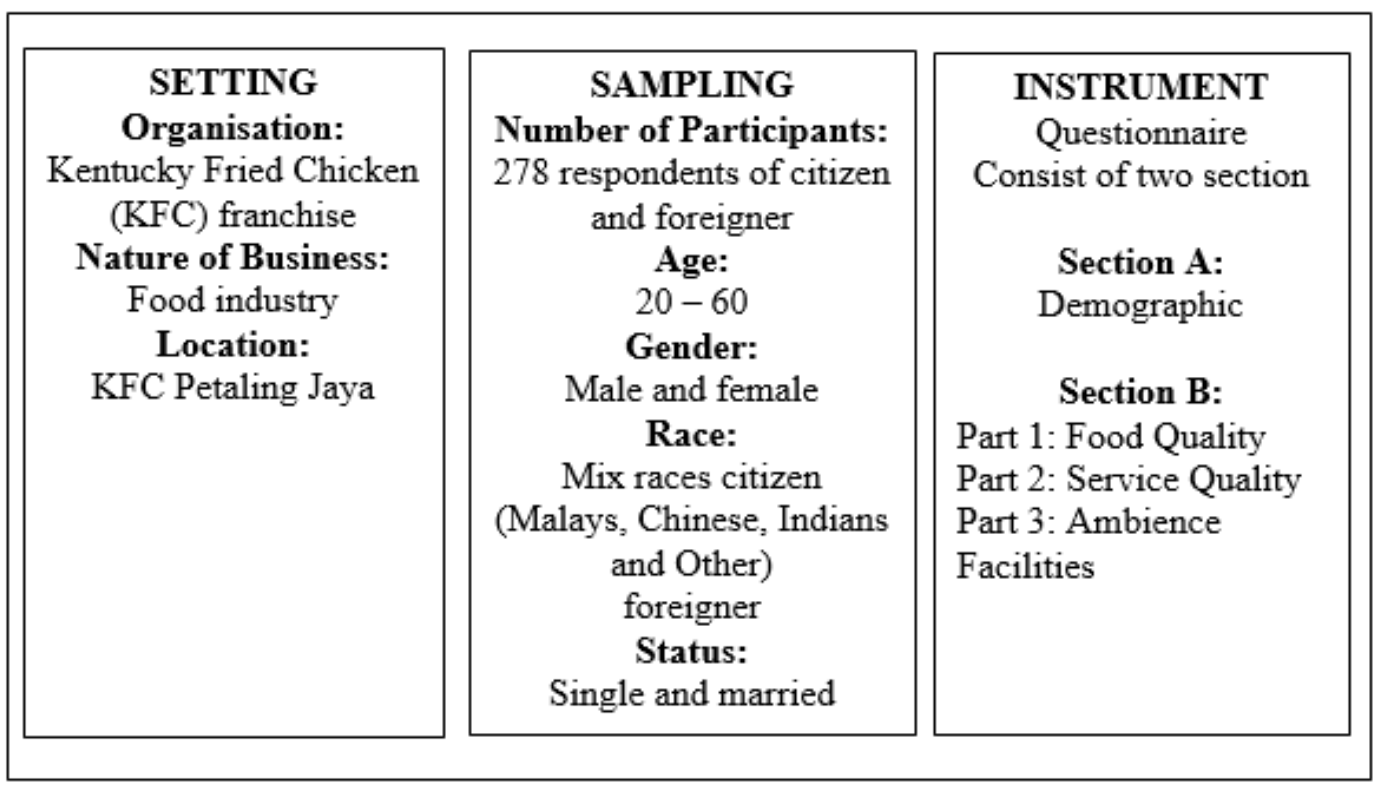

Figure 2. Research Design

There were 295 respondents involved in the present study from a population of 1,000 customers estimated to visit the restaurant every day. The sampling was conducted based on Kerjice and Morgan's (1970) sampling plan. A questionnaire was used to collect the data. The questionnaire was adapted from a previous study by Dipesh and Apil (2018) on restaurant customer satisfaction. The Cronbach's alpha test was done, and it showed above 0.8. As mentioned by Howitt and Cramer (2005), if the Cronbach's alpha results in a value above 0.8 , the instrument is acceptable and valid to use in research.

For the present study, a pilot test was done, which produced a result of 0.855 , which was also acceptable, as noted by Howitt and Cramer (2005). The questionnaire responses were based on a Likert scale (Likert, 1932) in the form of agree, disagree, neutral, strongly agree and strongly disagree. The questionnaire consisted of two sections: Section A for demographics and Section B for the factors that influence customer satisfaction toward KFC. The data were analysed based on the conceptual framework shown in Figure 1. SPSS version 25 was used for statistical analyses, and Pearson and correlation analyses were used based on the objectives of the present study.

\section{Data Collection and Data Analysis Procedures}

A questionnaire was used as the main source to collect the data. The first procedural step was to obtain ethical clearance, which involved the researcher getting written permission from the management of University of Malaya Centre for Continuing Education (UMCCed) and verbal permission from the manager of KFC Petaling Jaya to conduct the survey. The second step was sampling and data collection from the customers of the KFC restaurant. Then, the pilot test was conducted to make sure that the questionnaires were clear and understandable to the respondents, who included bilinguals speaking English and Bahasa Melayu. After that, the questionnaire was distributed to 278 respondents. The reliability and validity tests from the previous study were used as the questionnaire was adopted from that study. 


\section{Reliability and Validity}

\section{Cronbach's Alpha}

Reliability testing was conducted to measure the consistency of the results when tested repetitively. The test used provides results in terms of coefficient alpha, or Cronbach's alpha, from the SPSS version 25 . The reliability test value was above 0.8 , indicating the reliability of the questionnaire according to Howitt and Cramer (2005), who stated that if the reliability test result is above 0.8 the instrument tested is valid to use in research. However, for the present study a pilot test was done with an alpha result of 0.855, which is acceptable as noted by Howitt and Cramer (2005). We conducted this alpha test based on previous questionnaire research by Dipesh and Apil (2018) to determine whether the questionnaire questions were suitable to use in Malaysia.

Table 1: Cronbach's Alpha

\begin{tabular}{ccc}
\hline Cronbach's Alpha & $\begin{array}{c}\text { Cronbach's Alpha Based on } \\
\text { Standardized Items }\end{array}$ & N of Items \\
\hline .855 & .854 & 15 \\
\hline
\end{tabular}

The study utilised Pearson correlations based on the objectives and the issue that no previous study had investigated the factors that influence customer satisfaction specifically at KFC Petaling Jaya, Malaysia. The research investigated respondents' perceptions of the services, food quality and ambiance provided by KFC Petaling Jaya. We conducted this research, as sated previously, because KFC received complaints about unhygienic conditions and bad attitudes among staff during working hours at that restaurant (Laeranduil, 2018).

\section{Analysis and Discussion}

This section is on the analysis of the data that resulted from the pilot test and subsequent use of the questionnaire distributed to the customers of KFC Petaling Jaya for the purpose of this research. For analysis of the data, the Pearson's correlation coefficient procedure was used. The data analysis will also be discussed in this section to include comparisons and similarities of our research with previous research. According to Pallant (2016), questionnaire responses can be quantitatively analysed using IBM SPSS, the results of which are provided in the following discussions.

\section{Pearson's Correlation Analysis}

A Pearson's correlation coefficient shows the quality, heading and immensity of the bivariate connections among every one of the factors measured at a provisional or proportion level. Hair et al. (2007) indicated the general guidelines about coefficient extent and the quality of the connections.

Table 2: The scale of Pearson's Correlation Coefficient

\begin{tabular}{ll}
\hline Scale of correlation coefficient & Value \\
\hline $0<\mathrm{r} \leq 0.19$ & Very Low Correlation \\
$0.2 \leq \mathrm{r} \leq 0.39$ & Low Correlation \\
$0.4 \leq \mathrm{r} \leq 0.59$ & Moderate Correlation \\
$0.6 \leq \mathrm{r} \leq 0.79$ & High Correlation \\
$0.8 \leq \mathrm{r} \leq 1.0$ & Very High Correlation \\
\hline
\end{tabular}


Table 3 shows the relationships between three variables. In the food quality aspect, it displays the correlation of the relationship between food quality and service quality and ambiance of facilities are 0.474 and 0.513 . This means the relationship is correlated, and both of the variables are relatively linked to each other. In the service quality aspect, it displays the correlation of the relationship between service quality and food quality and ambiance of facilities are 0.474 and 0.626 . This means the relationship is correlated, and both of the variables are relatively linked to each other. In the ambiance facilities aspect, it displays the correlation of the relationship between ambiance facilities, food quality and service quality are 0.513 and 0.626 . This means the relationship is correlated and both of the variables are relatively linked to each other. The results indicate no multicollinearity problem as the correlations between variables are all less than 0.90 (Hair et al., 2006, p. 227).

Table 3: Correlations between variables

\begin{tabular}{|c|c|c|c|c|}
\hline & & Food quality & Service quality & Ambiance facilities \\
\hline \multirow[t]{3}{*}{ Food quality } & Pearson Correlation & 1 & $.474^{* *}$ & $.513^{* *}$ \\
\hline & Sig. (2-tailed) & & .000 & .000 \\
\hline & $\mathrm{N}$ & 294 & 294 & 294 \\
\hline \multirow[t]{3}{*}{ Service quality } & Pearson Correlation & $.474^{* *}$ & 1 & $.626^{* *}$ \\
\hline & Sig. (2-tailed) & .000 & & .000 \\
\hline & $\mathrm{N}$ & 294 & 294 & 294 \\
\hline \multirow[t]{3}{*}{ Ambiance facilities } & Pearson Correlation & $.513^{* *}$ & $.626^{* *}$ & 1 \\
\hline & Sig. (2-tailed) & .000 & .000 & \\
\hline & $\mathrm{N}$ & 294 & 294 & 294 \\
\hline
\end{tabular}

\section{Discussion}

Based on the results of this study, it is obvious that ambiance of facilities is the most important factor that influences customer satisfaction towards KFC Petaling Jaya. As a consequence, the company should focus more on this factor. Previous studies have reported that service quality influenced customer satisfaction. According to Dipesh Karki and Apil Panthi's (2018) research, the factors of price, service quality, ambiance of restaurant and food quality had effects on customer satisfaction in Nepalese restaurants. They also had the same independent variables but included the additional unique element of price. However, the ambiance of facilities did not directly affect customer satisfaction toward their restaurants.

Chalal and Naail Mohammad Kamil's (2017) objective was to study the relationships of three independent variables, which were service and food quality and atmosphere of fast food restaurants. This study found that the three independent variables influenced customer satisfaction. Dastane and Intan Fazlin's (2017) study investigated relationships between price, service and food quality, facilities and emotional factors on customer satisfaction. All factors had impacts on customer satisfaction, but the most significant found in this past study were emotional factors and facilities.

Even though the main important factor that influenced customer satisfaction with KFC Petaling Jaya was found to be ambiance of facilities, the company should not ignore other factors such as customer emotions, service and food quality, price and others. This is because to maintain customer satisfaction towards their products, the company should maintain any other factors and focus on improving the main factors that influence customer satisfaction with the products. Based on this research, surprisingly, an unexpected result occurred, which is that food quality was found to be a moderate factor in customer satisfaction with the products. This may be because the respondents prioritized the ambiance and service quality over the food quality offered. They were willing to come more frequently to KFC Petaling Jaya if the ambiance of the facilities was acceptable rather than another factor. 
The following part of this discussion briefly covers the implications of this study in comparison with past studies. They will be discussed in more detail in the section below on implications of the study.

One of the implications of this study is that it may benefit brand managers by providing the information collected from the customers of KFC. We found similarities between this study and past research which support the implication that managers should maintain the cleanliness of the facilities to make the restaurant comfortable for all the customers. This is supported by Dastane and Intan Fazlin's (2017) study, which was meant to investigate relationships between price, service and food quality, facilities and emotional factors to customer satisfaction. All factors had impacts on customer satisfaction, but the most significant found in this past study were emotional factors and facilities. This perspective can help managers to put themselves in the consumer's position, and the strategies they adopt will then be easily accepted by customers.

The above analysis shows that the three main factors, ambiance of facilities, service and food quality, impact customer satisfaction. The three research hypotheses related to these variables for this study are stated in Table 4 along with the results for each.

Table 4: Hypothesis Results

\begin{tabular}{lll}
\hline \multicolumn{2}{c}{ Hypothesis } & Results \\
\hline H1 & The relationship between food quality and customer satisfaction. & Positive \\
H2 & $\begin{array}{l}\text { The relationship between service quality and customer } \\
\text { satisfaction. }\end{array}$ & Positive \\
H3 & $\begin{array}{l}\text { The relationship between ambiance facilities and customer } \\
\text { satisfaction. }\end{array}$ & Positive \\
\hline
\end{tabular}

All the proposed hypotheses were accepted because according to the analysis, customers who were satisfied with the given variables were ultimately satisfied with the overall experience of dining in KFC Petaling Jaya. A restaurant is not just composed of the food or menu it is offering, it is a combination of many factors which pave the way to satisfaction of the customers who visit the restaurant. If even one of the factors is not adequately met, or poorly implemented, the customers would visit once, but will not refer it to others and will not visit again.

KFC Petaling Jaya is doing a great job by serving customers with utmost care. This research may serve as a guide for a fast food restaurant like KFC on what factors customers are seeking in such restaurants. Food quality, service quality and ambiance are the most important factors which some restaurants offer and ultimately affect the overall customer satisfaction and dining experience.

As a matter of fact, KFC is a well-established and renowned company, which has been running well for generations; they have their stability in the market and are top ranked. Although the company is stable, they still have to maintain their position and retain customers and gain their loyalty by making them as satisfied as possible. If customers are satisfied with a restaurant, they will be loyal to it and would come again, and with positive word of mouth, refer it to other people as well.

Although research highlighted many factors which are responsible for customer satisfaction, many other factors can be considered while creating customer loyalty and customer satisfaction. In agreement with past studies, further studies can focus on more independent variables, for instance customers' characteristics and their perceptions, product pricing, emotional factors, hygiene of premises, and customer loyalty and how these affect customer satisfactions with a dining experience in a restaurant. Although the factors used in this research are representative of a restaurant's perspective, the consumer's perspective also affects customer satisfaction to a great extent, which can be studied in future research. 
Based on this research, the only factor that supported customer satisfaction is the ambiance of facilities, but this does not mean that the other factors are unnecessary. Although the research found that the most significant factor impacting customer satisfaction was ambiance of facilities, the three factors considered in this research have correlational relationships with customer satisfaction. This means that managers should not ignore the other factors that can influence customer satisfaction as all of the factors will contribute to the satisfaction of consumers with KFC Petaling Jaya. Even though KFC is a well-known brand, they should always maintain and improve their food and service quality because it is hard to get customer satisfaction but easy to lose it.

The purpose of this research was to identify the factors that influence customer satisfaction toward KFC Petaling Jaya. This research was conducted on 294 respondents. The survey comprises two sections and responses are collected on five-point Likert scales. The study found a high degree of positive correlation among the independent and dependent variables, indicating that customer preference is dependent on various customer satisfaction factors including ambiance of facilities, service and food quality, which significantly influence the customers toward increased customer satisfaction with KFC Petaling Jaya.

\section{Implications of the Study}

The findings of the case study highlight some practical implications useful to management. Managers should maintain the cleanliness of the facilities to make the restaurant comfortable for all the customers. The research found that hygiene (cleanliness) encourages customers to come more frequently to KFC Petaling Jaya. In addition to that, another main implication of the study is it provides managers with a scientifically-based means to ascertain the service quality, food quality and ambiance of their own operations is a realistic and highly practical way. The expenditures in employee training and improving the food quality should be regarded as necessary investments. The service providers should thus pay close attention to training and empowering their service employees to enhance the dining experience to an impressive one for their customers.

It is imperative in today's business environment to use customer satisfaction measures to improve organisational performance. This can be accomplished easily because customers can convey or express their satisfaction with dining in KFC by simply answering questionnaires. Successful business owners and managers realise that keeping customers costs less than finding new ones. If certain practices drive customers away, a business repeatedly spends time and money on advertising and other efforts to recruit more. These business owners know that weaknesses in the production or delivery of goods lead to distressed customers, so they can use surveys to collect feedback. Customer satisfaction surveys can become essential tools for improving business and ensuring customers are happy and loyal.

\section{Limitations of the Study}

A few limitations were encountered while conducting this study which could become an inconvenience to further studies. The first limitation is that the survey was carried out at only one location, which may not be representative of other areas in Kuala Lumpur or the rest of Malaysia, and thus the result is not applicable to other areas besides KFC in Petaling Jaya. Next, this study was based on KFC customer perceptions which could change according to time, trends, lifestyle and other factors. Besides that, there was the possibility of a gap between what respondents may have thought and the survey responses they actually chose due to lack of time and having to rush to get their work done.

Furthermore, it was impossible to collect highly accurate data because some of the questionnaires had to be rejected due to incomplete answers. Also, the veracity of information provided by the customers could not be verified. They may have experienced reservations in giving candid responses on some of the information when filling up the questionnaire due to a perceived lack on anonymity. 


\section{Conclusion}

In conclusion, based on the questionnaire, the research concludes that Kentucky Fried Chicken (KFC) Petaling Jaya has provided good service to their customers. All the information resulting from the study could facilitate restaurant management in further enhancing the ambiance of facilities, service and food quality towards customer satisfaction at KFC Petaling Jaya.

Finally, no previous study has investigated ambiance and hygiene of facilities as factors influencing customer satisfaction with KFC Petaling Jaya. Although this study has limitations, these are not barriers to conducting research based on this study. Hopefully, this research will contribute to an understanding of customer satisfaction towards ambiance, service and food quality in KFC Petaling Jaya and its findings and recommendations can serve as a basis for continued future research on these topics.

As a recommendation for further research, studies could include more independent variables. Aside from the three independent variables in this research, there are many other factors that contribute to customer satisfaction. Other factors that can influence customer satisfaction are price and promotion, for example. Furthermore, researchers can expand the research setting from one location to several branches. In addition, to ensure sampling representativeness, future researchers should increase the sample size while conducting their questionnaire survey. In doing this, the research study will become more valuable and reliable. In the future, researchers can also utilize this research as a reference, incorporating the design of this research into their own research.

\section{References}

Abdul, R.M., Zainal, A. (2016), The effect of customer perceived value on customer satisfaction: A case study of Malay upscale restaurants. Malaysian Journal of Society and Space, 12(3), 58-68.

Almohaimmeed, B. M. (2017). Restaurant quality and customer satisfaction. 7(3), 42-49.

Al- Tit, A. A. (2015). The effect of service and food quality on customer satisfaction and hence customer retention. Asian Social Science, 11(23), 129-139.

Basnayake, R., \& Hassan, Z. (2015). Employees ethical behaviour and its effect on customer satisfaction and retention: An empirical study on multinational fast food restaurants in Malaysia. International Journal of Accounting, Business and Management,3(1), 1-16.

Bhagat, S. (2016). An empirical analysis on customer satisfaction level in fast food industry among the major competitor's [Delhi- NCR]. International Journal of Advanced Scientific Research and Management, 1(10), 23-29.

Boonmee, S., Thanyasunthornsakun, K., Chanthavone, T., Silipanya, D., Amornpinyo, N., \& Uamturapojn, P. (2016). Leveraging service quality of resorts and hotels in Luang Prabang by integrating S ERVQUAL and Kano's Mode. Pertanika Journal Social Science and Humanities, 24, 73-88.

Chahal, D. K., \& Kamil, D. M. (2017). The determinants of customer satisfaction and behavioral intention among restaurant in Klang Valley area of Malaysia: A Conceptual Study. Journal of Social Sciences and Humanities, 12(02), 307-317.

Creswell, J. (2014). Research design: Qualitative, quantitative, and mixed methods approaches (4th ed.) SAGE Publications, Inc.

Danish, R. Q., Shakir, W., Tariq, S., Ali, H. F., Khan, M. A., \& Shahid, R. (2018). Determinants of loyalty through customer satisfaction, evidence form fast food industry of Lahore, Pakistan. International Journal of Scientific \& Engineering,9(12), 10-28.

Dao, N., Tin, N. (2015), The Influence of Service Quality on Customer Satisfaction and Loyalty at Restaurant in Ho Chi Minh City, Vietnam. The International Conference on Finance and Economics Ton Duc Thang University, Ho Chi Minh City, Vietnam, June 4th-6th. p1-22.

Haider, M. U., Jan, F. A., Jan, M. F., \& Jan, M. F. (2007). Factors effecting brand preferences: A comparative study of McDonald's and KF. Abasyn Journal of Social Sciences, 5(2), 28-42. 
Hanaysha, J. (2016). Testing the effects of food quality, price fairness, and physical environment on customer satisfaction in fast food restaurant industry. Journal of Asian Business Strategy, 6(2), 31-40.

Hasan, M. R., Polas, Rahman, M. M., Miah, M. A., \& Ali, M. M., Hayash. (2018). The impact of waiting time towards customers' satisfaction in fast food establishments: Evidence from Bangladesh. IOSR Journal of Business and Management (IOSR-JBM), 20(05), 11-21.

Herman, R., Widiasari, J., Lasmy, \& Hartono, H. (2016). How popular culture affects brand identity and perceived quality in consumer decision making. Pertanika Journal Social Science and Humanities, 24, 9-18.

Howitt, D., \& Cramer, D. (2005). Introduction to statistics in psychology. Harlow: Pearson Hall.

Hui, E. C., \& Zheng, X. (2010). Measuring Customer Satisfaction of FM Service in Housing Sector: A Structural Equation Model Approach. Facilities, 28(5), 306-320.

Jackson, S. L. (2012). Research methods statistics. (4th ed.)Chigago,NY:WadsworthCengage Learning.

Jaini, A., Ahmad, N., Zaib, S. (2015), Determinant factors that influence customer' experience in fast food restaurants in Sungai Petani, Kedah. Journal of Entrepreneurship and Business, 3(1), 6071.

Karki, D., \& Panthi, A. (2018). How food quality, price, ambiance and service quality effects customer satisfaction: A study on Nepalese Restaurants in Finland. 1-38.

Krejcie, R. V., \& Morgan, D. W. (1970). Determining sample size for research activities. 30, 607-610.

Lahap Johanudin, Azlan, R.I. \& Bahri, K.A. \& Said Noraslinda Abdullah, Dahlan \& Zain Razlan. (2018). The effect of perceived waiting time on customer's satisfaction: A focus on fast food restaurant. International Journal of Supply Chain Management. 7 (5)259-266.

Likert, R. (1932). A technique for measurement of attitude. Archives of Psychology, 140, 5- 55.

Md. Sawari, S. S., Ghazali, M. A., Ibrahim, M. B., \& Mustapha, N. I. (2015). Evidence based review on the effect of Islamic Dietary Law towards human development. Mediterranean Journal of Social Sciences, 6(3), 136-141.

Muala, A. A. (2018). Influence of Viral Marketing Dimensions on Customer Satisfaction in Fast Food Restaurants in Jordan. Journal of Management and Sustainability, 8(1), 149-155.

Mushtaq, N. Mirza, H.H. and Ali Asghar, Muhammad, J.K. (2012). Service Quality Gap and Customer Satisfaction Among Public versus Private Hospitals of Pakistan. Social Science International Journal of Business and Management Research, 2 (1), 111-124.

Mustafa, A., Adnan, N., \& Mohd nawayai, S. (2017). The influence of product quality and service quality on house buyer's satisfaction in Prima Home. Pertanika Journal of Social Science and Humanities, 25(4), 1841-1852.

Ngoc, K., Uyen, T. (2015), Factors affecting guest perceived service quality, product quality, and satisfaction - A study of luxury restaurants in Ho Chi Minh City, Vietnam. Journal of Advanced Management Science, 3(4), 284-291.

Nunnally, J. C. (1978). Psychometric theory ( $2^{\text {nd }}$ ed.). New York: McGraw-Hill.

Olise, M.C., Okoli, M.I., \& Ekeke, J.N. (2015). Factors influencing customer's patronage of fast food restaurant: A Study of selected customers of fast food in Anambra State, Nigeria. International Journal of Economics, Commerce and Management, 3(11), 686-701.

Pallant, J. (2016). SPSS survival manual: A step by step guide to data analysis using IBM SPSS(6th ed.).

T. M. (2018, June 14). Netizen Urged KFC Malaysia To Raise Quality Control For All Their Outlets. Retrieved from https://thecoverage.my/news/malaysia/netizen-urged-kfc-malaysia-to-raisequality-control-for-all-their-outlets/

Rizwan Qaisar, Shakir Waqas Tariq, Shahan Ali, Hafiz Fawad, Khan Muhammad and Shahid Rabia. (2018). Determinants of Loyalty through customer satisfaction; evidence from Fast Food Industry of Lahore. International Journal of Scientific and Engineering Research, 9 (12), 10-18.

Sekaran, U. (2003). Research methods for business: A skill-building approach(4th ed.).

Shariff, S.N., Omar, M., Sulong, S.N., Majid, H., Ibrahim, H., Jaafar, Z., Ideris, M. (2015), The influence of service quality and food quality towards customer fulfillment and revisit intention. Canadian Social Science, 11(8), 110-116.

Sumaedi, S., Yarmen, M. (2015), Measuring perceived service quality of fast food restaurant in Islamic country: A conceptual framework. Procedia Food Science, 3, 119-131 
DOI: https://doi.org/10.47405/mjssh.v5i4.390

Szwarc, Paul. Researching Customer Satisfaction \& Loyalty (How to findout what people really think). London: Kogan Page, 2005. ISBN 0-7494-4336-7

Szymanski, D. M. \& Henard, D. H. (2001). Customer satisfaction: A meta-analysis of the empirical evidence. Journal of the Academy of Marketing Science, 29 (1), 16-35.

Ya, S., Noor, S. M., Nor, M., \& Ahmad, Z. (2017). Purchase intention of Islamic brand product among nonMuslim customers. Pertanika Journal Social Science and Humanities, 25(8), 101-110.

Yee, W. F., Ling, C. S., \& Leong, L. K. (2015). Factors affecting customer loyalty in the telecommunications industry in the Klang Valley, Malaysia. Pertanika Journal Social Sciences and Humanities, 23, 117-130.

Zalatar, W. F. (2017). Service quality and customer satisfaction in fast food restaurant: A customer comparison using discriminant analysis. 